\title{
Thermal and cost analysis of float and various tinted double window glass configurations on heat gain into buildings of hot $\&$ dry climatic zone in India
}

\author{
Kirankumar Gorantla ${ }^{1 *}$, Saboor Shaik ${ }^{2}$, Ashok Babu Talanki Putta Ranga Setty ${ }^{1}$ \\ ${ }^{1}$ Mechanical Engineering Department, National Institute of Technology Karnataka, Surathkal, Mangalore-575025, Karnataka, \\ India \\ ${ }^{2}$ Department of Thermal and Energy Engineering, VIT University, Vellore-632014, Tamilnadu, India \\ Corresponding Author Email: gorantla.kirankumar@gmail.com
}

https://doi.org/10.18280/ijht.360134

Received: 13 November 2017

Accepted: 15 January 2018

\section{Keywords:}

spectrophotometer, glass window, solar optical properties, and double glass window.

\begin{abstract}
Glass window enclosures for buildings consume a lot of energy for affording thermal and visual comfort. Reducing solar radiation in summer and increase in winter through different double window glasses for making energy efficient building design is the theme of this paper. Therefore this work measures the spectral characteristics of four glasses namely grey, green, bronze and clear glasses in entire solar spectrum region from $300 \mathrm{~nm}$ to $2500 \mathrm{~nm}$ at normal angle of incidence by using Shimadzu UV 3600 spectrophotometer based on ASTM standards To find the solar optical properties a MATLAB code was used which is based on British standards. To find the solar radiation transmission from different double window glass configurations and cost analysis from eight coordinal directions at peak summer and winter day were selected as per Indian standards with a MATLAB code to hot and dry climatic zone of Jodhpur (26.300N, 73.020E). From these results it is shows that in south direction all double glass windows are gaining less heat in summer and more heat in winter season when compared to other orientations. It is found that south orientation C1(Greyglasswindow-Airgap10mmGreenglasswindow) and C12(Clearglasswindow-Airgap10mm-Bronzeglasswindow) configuration windows are gaining minimum and maximum heat in summer and winter respectively when compared to other configuration windows. Among all windows C1 configuration window is saving more cost annually.
\end{abstract}

\section{INTRODUCTION}

More amount of energy is required for day lighting, heating and cooling loads for building as they provide thermal and visual comfort to the occupants inside the building. Providing visual comfort to the occupants form inside and outside the building is possible only with window glasses, thus window glasses plays an important role by using them as building enclosures. From architectural approach many multinational companies and commercial buildings are using different glass enclosures for their building to increase their attractiveness in present days. Extra quantity of heat gain is emitted by the usage of extensive glass enclosures which generates uncomfortable conditions with building envelopes, to get rid of this transparency researchers and building engineers are focusing on various solar control window glass materials to provide visual and thermal comfort by consuming minimum energy into the buildings.

Previous authors have worked on different window glass materials and found how the solar radiation passes into the buildings. Study of float and tinted glasses of single glazing and double glazing filled with air, xenon, krypton and to find how the solar radiation passing into the buildings by using TRANSYS to different climatic zones in India were reported in [1]. To find the minimum heat gain into buildings by various walls and window glass material buildings at different window to wall ratios for energy efficient building design in warm and humid climatic zone of Indian city of Mangalore were reported in [2]. Study of clear and brown window glass material when tilted in inward direction the glass would reduce solar beam radiation to transmit into buildings in both summer and winter season of Baghdad city in Iraq country were reported in [3]. The comparison and validation of mathematical model and experimental results of finding the solar radiation transmit into buildings on $4 \mathrm{~mm}$ clear glass was reported in [4]. This paper focuses on finding the minimum heat gain into building by arranging various wall and window glass materials at $30 \%$ window to wall ratios in different orientations to find the energy efficient building design in all Indian climatic zones were reported[5]. To measure the spectral characteristics of clear, double Low-E and Triple Low-E glasses and by evaluating these results to find the solar radiation through glass windows, to obtain energy efficient glass design for buildings was studied in detail [6]. Study of various single, double LowE glazing's, thermo tropic and photovoltaic windows by using them as building envelope in all orientations to find which would minimise the solar energy consumption in the building for different climatic regions in Malaysia country were reported in detail [7]. To find out the heat transfer through single Low-E and double Low-E glass windows considering the entire wave length region in solar spectrum by changing the position of window glasses to decrease the solar radiation in summer and to increase the solar radiation in winter seasons for an adiabatic room was studied [8].To find the direct solar radiation into buildings at various inward window tilt glasses in all directions of buildings, for six latitudes of India and 
found that in south direction it achieved zero radiation for all the four different window glass materials like clear, bronze, green and bronze reflective were studied in [9]. To analyze the heat transfer through internal louvered blind with high and low thermal conductivity in double-glazed unit to find the thermal transmittance by using and comparing a biquadratic equation and also with computational fluid dynamics at different places was studied [10]. Find the solar radiation through single window glass in buildings of float and tinted glasses at peak summer day of different Indian climatic zones was studied [11].

Influence of various geometries roof construction, sun shields and window glass materials like Low-E glass by using them as building envelopes to residential buildings for reducing energy consumption as well as to save electricity monthly and annually of Taiwan by EQUEST software were studied in detail [12]. A detailed study has been done on different insulation materials used in the external walls of apartment building and found increasing energy performance of the building'sby consideringthermal, moisture and cost analysis and these results vary not only on external temperatures and also vapour pressureto evaluate the most suitable integrated solutions, avoiding moisture problems for different location was described[13]. To test and compare the three different plate collectors on top of the chemical industry office building for whole year in Mediterranean Area to provide cooling inside with the help of solar energy in the southern part of Italy by using NEGST softwareand concludes that which collector is suitable for different seasons like summer and winter[14]. At present there are no significant studies on thermal performance of float and various tinted glasses keep as double glass window and also on the net cooling and heating cost savings of the glasses. To fulfill these gaps, this paper aims to find thermal performance of float and tinted window glasses such as grey, green, bronze and clear glasses. All these window glasses are tested for reducing the annual net cooling and heating costs in all eight orientations of hot and dry climatic zone in India.

\section{EXPERIMENTAL METHODOLOGY}

For measuring the spectral characterisitics like transmission and reflection of any glass windows Shimadzu UV 3600 spectrophotometer is used as an instrument to measure the data in entire solar spectrum wavelength range from $300 \mathrm{~nm}$ to $2500 \mathrm{~nm}$ i.e. (Ultraviolet, Visible and Near Infrared) of four glasses which include grey, green, bronze and clear glasses of size $30 \mathrm{mmX} 30 \mathrm{~mm}$ and thickness of $5 \mathrm{~mm}$ at normal angle of incidence were taken into consideration while doing this work by using ASTM E 424 standard method [13]. Fig 1 shows the Shimadzu UV 3600 spectrophotometer interfaced with UV Win lab software and Fig. 2 shows the images of window glasses. By using British and ISO standards BS EN 410 \& ISO 2003 [14, 15] with the following Eq. (1) to Eq. (3) a MATLAB code was developed to compute the solar optical properties like transmittance and reflectance of glasses in entire solar spectrum wave length region i.e. $300 \mathrm{~nm}-2500 \mathrm{~nm}$.

$T_{S L}=\sum_{\lambda=300}^{\lambda=2500} S_{\lambda} \tau(\lambda) \Delta \lambda / \sum_{\lambda=300}^{\lambda=2500} S_{\lambda} \Delta \lambda$
$R_{S L}=\sum_{\lambda=300}^{\lambda=2500} S_{\lambda} \rho(\lambda) \Delta \lambda / \sum_{\lambda=300}^{\lambda=2500} S_{\lambda} \Delta \lambda$

Solar absorbance of the glass can be found by knowing the transmittance and reflectance. Table 1 shows the solar optical and solar heat gain coefficient of glass windows.

$A_{S L}=1-\sum_{\lambda=300}^{\lambda=2500} S_{\lambda} \tau(\lambda) \Delta \lambda / \sum_{\lambda=300}^{\lambda=2500} S_{\lambda} \Delta \lambda-\sum_{\lambda=300}^{\lambda=2500} S_{\lambda} \rho(\lambda) \Delta \lambda / \sum_{\lambda=300}^{\lambda=2500} S_{\lambda} \Delta \lambda$

Solar heat gain coefficinent factor is defined as the ratio of solar heat gain that passes through the fenestration to the total incident solar radiation that falls on the fenestration. Solar heat gain coefficient is an important and useful factor of any window glass to find the heat gain and to know how much radiation passing into the buildings. The mathematical correlation of solar heat gain coefficient of single window glass is given below Eq. (4) and double window glass is given in below Eq. (5). Generally solar heat gain coefficient of any window glass is in between 0 to 1 . If the solar heat gain coefficient of the glass is more solar radiation passing through window glass is more and vice versa.

$$
\begin{aligned}
& S H G C_{S G}=\left(T_{S L}+\frac{U}{h_{o}} A_{S L}\right) \\
& S H G C_{D G}=\left(T_{S L}+U\left(\frac{\alpha_{i}+\alpha_{o}}{h_{o}}+\alpha_{i} X C_{A G}\right)\right)
\end{aligned}
$$

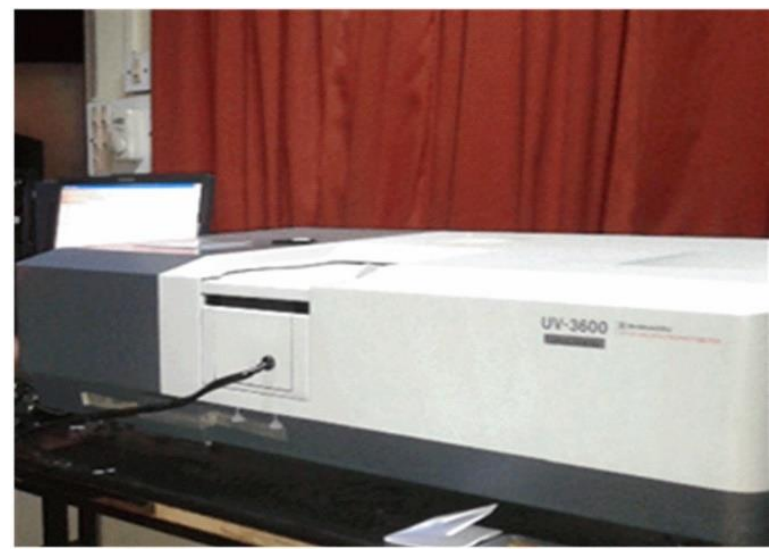

Figure 1. UV-3600 Shimadzu spectrophotometer with interfaced UV-Win lab software

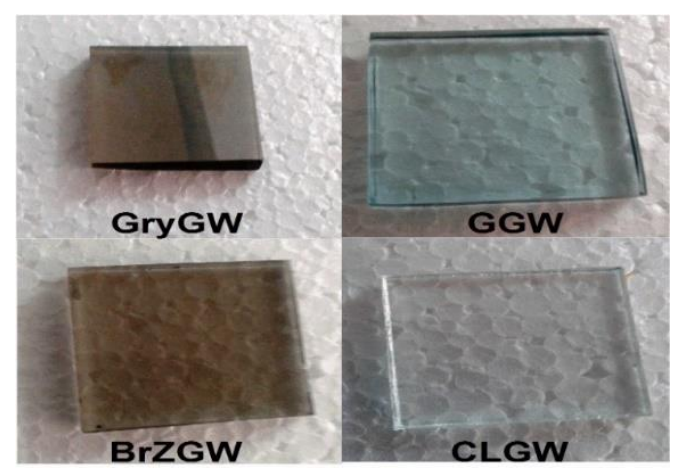

Figure 2. Images of window glasses 
Table 1. Solar optical and solar heat gain coefficient of glass windows in solar spectrum region

\begin{tabular}{cccccc}
\hline Window Glass & Code & $\begin{array}{c}\mathrm{T}_{\mathrm{SL}} \\
{[\%]}\end{array}$ & $\begin{array}{c}\mathrm{R}_{\mathrm{SL}} \\
{[\%]}\end{array}$ & $\begin{array}{c}\text { ASL } \\
{[\%]}\end{array}$ & $\begin{array}{c}\text { SHGC } \\
{[\%]}\end{array}$ \\
\hline Grey glass & GryGW & 41 & 6 & 53 & 53 \\
Green glass & GGW & 47 & 6 & 47 & 58 \\
Bronze glass & BrZGW & 56 & 6 & 38 & 65 \\
Clear glass & CLGW & 82 & 8 & 10 & 84 \\
\hline
\end{tabular}

Fig. 3 and Fig. 4 show the spectral transmission and reflection cure data of all glass windows which are obtained from experiments. For each glass is obtain different curve i.e. because it depends on chemical properties of glass. From the figure 3(a) it is clearly shown that clear glass is having more transmission and grey glass is having less transmission compared to all other glass materials. These properties are very important to find the solar optical properties of glass windows like transmittance and reflectance to calculate the solar heat gain coefficient.

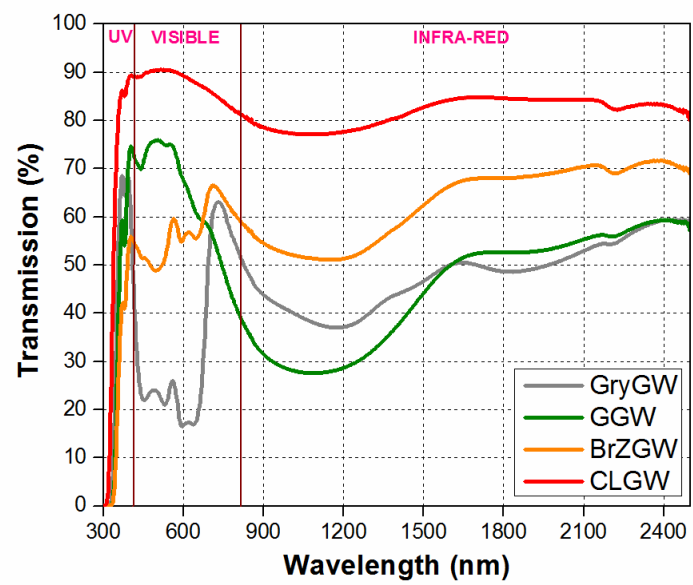

Figure 3. Spectral transmission of glass windows

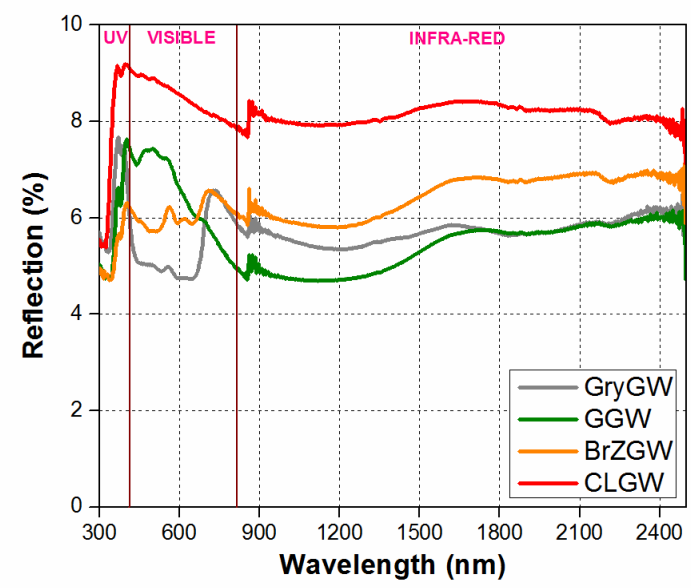

Figure 4. Spectral reflection of glass windows

\section{NUMERICAL METHOD}

Solar radiation which is in the form of electromagnetic waves i.e extra-terrestrial radiation outside the earth's surface is known as short wave radiation and it differs into short and long wave radiation when it touches the earth surface. Solar radiation wavelength region which is in the form of electromagnetic waves is $0.2 \mu \mathrm{m}-10 \mu \mathrm{m}$. In which ultra violet region is $(0.3 \mu \mathrm{m}-0.38 \mu \mathrm{m})$, visible region is $(0.38 \mu \mathrm{m}-0.78 \mu \mathrm{m})$, near infrared region is $(0.78 \mu \mathrm{m}-2.5 \mu \mathrm{m})$ infrared region $(2.5 \mu \mathrm{m}-10 \mu \mathrm{m})$. Direct radiation from the sun, diffuse radiation from the sky and reflected radiation from the ground is the three different form of solar radiation passing into building through the glass materials. The solar spectrum wave length region, which is used to find the total solar radiation i.e. direct, diffuse and reflected ground radiation falling on building enclosures should be $0.3 \mu \mathrm{m}$ to $2.5 \mu \mathrm{m}$.

Several factors like hour angle, declination angle, solar altitude, solar azimuth angle, surface solar azimuth angle and angle of incidence of latitude are to be considered while finding the three types of radiation namely direct, diffuse and reflected ground radiation. In this present work to find the total solar radiation at peak summer from morning 6:00 to evening 18:00 and peak winter day from morning 7:00 to evening 17:00 are considered by using double glazing windows with an unventilated air gap of $10 \mathrm{~mm}$ between glasses as per Indian standards [16-18] in all eight coordinal orientations like east, west, north, south, southeast, southwest, northwest and northeast for all climatic zones of clear sky conditions and cloudy sky conditions.
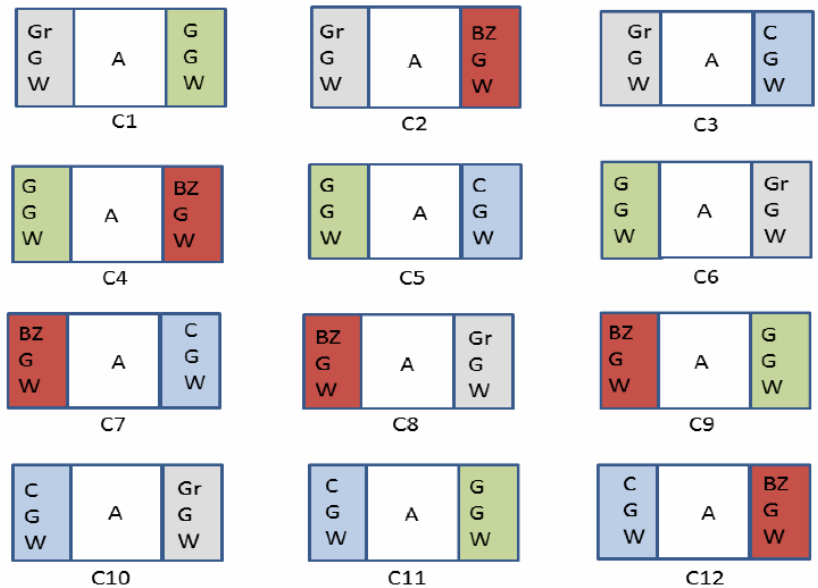

Figure 5. Double glass window configurations with an air gap $10 \mathrm{~mm}$

Table 2. Values of Constants A, B and C Obtained for Predicting Hourly Solar Radiation in India (Ref 20)

\begin{tabular}{cccc}
\hline Day & $\begin{array}{c}\text { Solar } \\
\text { radiation in } \\
\text { absence of } \\
\text { atmosphere } \\
\text { A }\left(\mathrm{W} / \mathrm{m}^{2}\right)\end{array}$ & $\begin{array}{c}\text { Atmospheric } \\
\text { extinction } \\
\text { coefficient } \\
\mathrm{B}\left(\mathrm{W} / \mathrm{m}^{2}\right)\end{array}$ & $\begin{array}{c}\text { Dimensionless } \\
\text { coefficient for } \\
\text { sky radiation } \\
\mathrm{C}\end{array}$ \\
\hline Jan. 21 & 610.00 & 0.000 & 0.242 \\
Feb. 21 & 652.20 & 0.010 & 0.249 \\
Mar. 21 & 667.86 & 0.036 & 0.299 \\
Apr. 21 & 613.35 & 0.121 & 0.395 \\
May. 21 & 558.39 & 0.200 & 0.495 \\
Jun. 21 & 340.71 & 0.428 & 1.058 \\
Jul. 21 & 232.87 & 0.171 & 1.611 \\
Aug. 21 & 240.80 & 0.148 & 1.624 \\
Sep. 21 & 426.21 & 0.074 & 0.688 \\
Oct. 21 & 584.73 & 0.020 & 0.366 \\
Nov. 21 & 616.60 & 0.008 & 0.253 \\
Dec. 21 & 622.52 & 0.000 & 0.243 \\
\hline
\end{tabular}

In this work hot \& dry climatic regions of Indian city Jodhpur $\left(26.30^{\circ} \mathrm{N}, 73.02^{\circ} \mathrm{E}\right)$ is selected to compute the total 
solar radiation through all double glazing window configurations. By arranging $40 \%$ window to wall ration i.e. $2.8 \mathrm{~m} \times 2 \mathrm{~m}$ dimensions for the building model with a dimensions of $4 \mathrm{~m} \times 4 \mathrm{~m} \times 3.5 \mathrm{~m}$ double window glass area, in all eight orientations like east, west, north, south, southeast, southwest, northeast and northwest when placed one after the other such that total thirty type double window reflective glass configuration were shown in figure 5 from $\mathrm{C} 1$ to $\mathrm{C} 12$ were considered as per ECBC standards [19]. These configurations were tried in all eight orientations such that total ninety six models were computed in this climatic zone to find the total solar radiation passing through these glasses by using ISHRAE clear sky and intermediate sky model at Jodhpur atmospheric conditions.

Table 2 shows the hourly solar radiation values of every month dated $21^{\text {st }}$ of different climatic regions in India.These values used to find the direct, diffuse and ground reflected radiation values on any surface.

The following are steps to find the direct diffuse and ground reflected radiation passing through window glass in buildings by using ISHRAE clear sky and intermediate sky model atmospheric conditions [21-22].

Declination angle

$d_{i}=23.45 \frac{\sin 360(284+N)}{365}$

Solar altitude angle

$\sin \beta=\cos l \cos d_{i} \cosh +\sin l \sin d_{i}$

Solar azimuth angle

$\cos \phi=\frac{\sin \beta \sin l-\sin d_{i}}{\cos \beta \cos l}$

Surface solar azimuth angle

$\gamma=\phi-\Psi$

Table 3. Surface orientations and azimuths, measured from south (ASHRAE 2001)

\begin{tabular}{ccc}
\hline S.No & Orientation & Surface Azimuth $\Psi$ \\
\hline 1. & North & $180^{0}$ \\
2. & North East & $-135^{0}$ \\
3. & East & $-90^{0}$ \\
4. & South East & $-45^{0}$ \\
5. & South & $0^{0}$ \\
6. & South West & $45^{0}$ \\
7. & West & $90^{0}$ \\
8. & North West & $135^{0}$ \\
\hline
\end{tabular}

Angle of incidence

$\cos \theta=\cos \beta \cos \gamma \cos k-\sin \beta \sin k$

At the earth's surface on a clear day solar irradiance at clear atmosphere is given by
$I_{D N}=\frac{A}{\exp (B / \sin \beta)}$

Intensity of direct solar radiation falling on glass

$I_{D R}=I_{D N} \cos \theta$

Diffused solar radiation from the sky falling on glass

$I_{d R}=C I_{D N} \frac{1-\sin k}{2}$

Reflected radiation from the ground surface falling on glass

$I_{G R}=(C+\sin \beta) I_{D N} \rho_{g} \frac{1-\sin k}{2}$

Total solar radiation falling on glass window

$I_{T S R G W}=\left(I_{D R}+I_{d R}+I_{G R}\right)$

Total solar radiation passing through single glass windows

$I_{T S R S G W}=\left(I_{D R}+I_{d R}+I_{G R}\right) \cdot\left(T_{S L}+\frac{U}{h_{o}} A_{S L}\right) \cdot A_{g}$

Total solar radiation passing through double glass windows

$I_{\text {TSRDGW }}=\left(I_{D R}+I_{d R}+I_{G R}\right) \cdot\left(T_{S L}+U\left(\frac{\alpha_{i}+\alpha_{o}}{h_{o}}+\alpha_{i} X C_{o}\right)\right) \cdot A_{g}$

where $\mathrm{C}_{\mathrm{o}}$ is the conductance of the air gap between two glasses

$C_{A G}=1 /\left(1.25+\left(2.32 X\left(\sqrt{\left(1+\left(\frac{t_{a}^{2}}{w_{a}^{2}}\right)\right)}-\frac{t_{a}}{w_{a}}\right)\right)\right)$

where $C_{o}, h_{i}, h_{o}$ values are taken from CIBSE standards [25]

Table 4. Theoretical validation of direct solar radiation passing through $3 \mathrm{~mm}$ clear glass of Ishwar et. al and present program results to New Delhi climatic region at peak summer day June $21^{\text {st }}$

\begin{tabular}{ccccc}
\hline S.No. & Orientation & $\begin{array}{c}\text { Ishwar et } \\
\text { al }(2011)\end{array}$ & $\begin{array}{c}\text { MATALAB } \\
\text { program } \\
\text { results }\end{array}$ & $\begin{array}{c}\text { Deviation } \\
(\%)\end{array}$ \\
\hline 1 & North & 178.3636 & 178 & -0.20 \\
2 & North East & 1289.98 & 1292 & -0.15 \\
3 & East & 1953.83 & 1952 & -0.09 \\
4 & South East & 1273.55 & 1272 & -0.12 \\
5 & South & 184.27 & 184 & -0.14 \\
6 & South West & 1273.55 & 1272 & -0.12 \\
7 & West & 1953.83 & 1952 & -0.09 \\
8 & North West & 1289.98 & 1292 & -0.15 \\
\hline
\end{tabular}

For the validation of present MATLAB code, $3 \mathrm{~mm}$ clear glass window was used as that of the previous researchers. The direct solar radiation results of New Delhi climatic region 
obtained from the MATLAB code are compared with Ishwar et.al (2011) results and they are listed in table 3. The deviation of MATLAB code results with Ishwar et al (2011) is less than $1 \%$. Therefore the developed MATLAB code is reliable and hence it can be used for the computation of solar radiation for different glasses.

\section{RESULTS AND DISCUSSIONS}

4.1 Solar radiation gain into buildings through double glass windows of Jodhpur (hot \& dry) climatic region in both summer and winter season

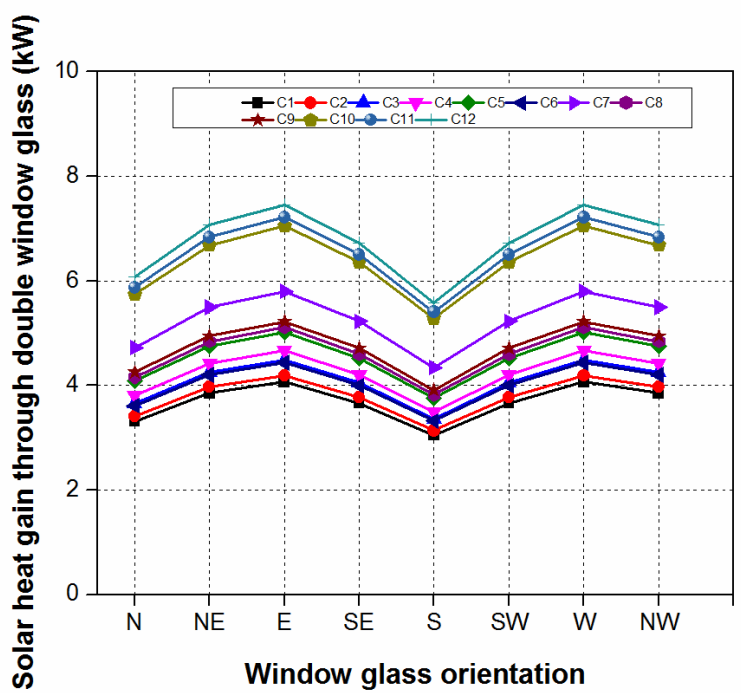

Figure 6. Total solar radiation passing through double glass windows from all orientations of Jodhpur climatic region in summer season

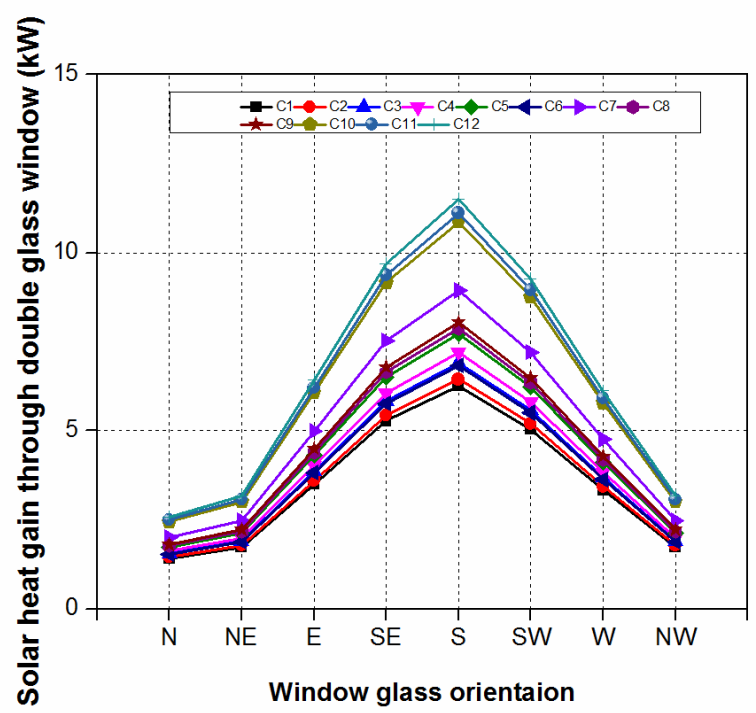

Figure 7. Total solar radiation passing through double glass windows from all orientations of Jodhpur climatic region in winter season

Fig. 6 shows the heat gain through different double window glass configurations of Jodhpur $\left(26.30^{\circ} \mathrm{N}, 73.02^{\circ} \mathrm{E}\right)$ climatic condition at peak summer day on June $21^{\text {st }}$ from morning 6:00 to evening 18:00. Form the graphs it is clearly observed that in south orientation of all double glass window configurations are gaining less heat when compared to other orientations in summer season. In south orientation $\mathrm{C} 1$ configuration window glasses are permitting less heat in south orientation at summer season compared to all other configuration window glasses, because of its less solar optical properties and solar heat gain coefficient values.

Fig. 7 shows the heat gain through different double window glass configurations of Jodhpur climatic condition at peak winter day on December $21^{\text {st }}$ as per Indian standards from all eight coordinal directions from morning 7:00 to evening 17:00 From the graph it is clear observed that all double glass windows are gaining more heat in south orientation, in which C12 configuration double glass window is gaining more heat in winter season when compared to all other window glass configurations.

4.2 Annual cost savings per year of double window glass configurations compared with double clear glass window configuration to Jodhpur (hot\& dry) climatic region

Fig. 8 shows the graph between twelve double window glass configurations saving annual cost in rupees per year compared with the double clear glass window in north orientation of Jodhpur climatic region. Finding the total cost savings in a year by using all double window glass unit procedure is given below for finding the total solar radiation in summer months and winter months, cooling load decreases in summer and heating load increases in winter season.

$$
\begin{aligned}
& Q_{\text {Sol, Summer }}=\left(q_{d s_{\text {April }}} X 30\right)+\left(q_{d s_{\text {May }}} X 31\right)+ \\
& \left(q_{d s_{\text {Jume }}} X 30\right)+\left(q_{d s_{\text {July }}} X 31\right)+ \\
& \left(q_{d s_{\text {August }}} X 31\right) \\
& Q_{\text {sol, winter }}=\left(q_{d w_{\text {Sep }}} X 30\right)+\left(q_{d w_{\text {Oct }}} X 31\right)+\left(q_{d w_{\text {Nov }}} X 30\right)+ \\
& \left(q_{d w_{\text {Dec }}} X 31\right)+\left(q_{d w_{\text {Jan }}} X 31\right)+ \\
& \left(q_{d w_{\text {Feb }}} X 29\right)+\left(q_{d w_{\text {Mar }}} X 31\right)
\end{aligned}
$$

Basing on the above equation cooling load decreases anually in summer season and heating load increases annually in wintere season is shown below

$$
\begin{aligned}
& \text { Cooling load decrease }= \\
& Q_{\text {Sol, Summer }} X A_{g} X\left(S H G C_{D C G W}-S H G C_{S D W G}\right)
\end{aligned}
$$

$$
\begin{aligned}
& \text { Hooling load increase }= \\
& Q_{\text {Sol, Wummer }} X A_{g} X\left(S H G C_{D C G W}-S H G C_{S D G W}\right)
\end{aligned}
$$

Decrease in cooling costs $=($ cooling load decrease $)$ (unit cost of electricity)/(COP)

Increase in heating costs $=$ (heating load increase) (unit cost of fuel)/(Efficiency)

The net annual cost savings $=$ Decrease in cooling costs increase in heating costs 
In the present study, the unit cost of the electricity and natural gas considered are ₹5.12 kWh and ₹32/therm, respectively. The coefficient of performance of the cooling system and efficiency of the furnace are taken as 2.5 and 0.8 , respectively, 1 Therm is equal to $29.31 \mathrm{kWh}$.

From the graph it is clearly shown that in the north orientation $\mathrm{C} 1$ configuration window glass is more energy efficient and it is also saving more cost when compared to all double window glass configurations i.e. $\mathrm{C} 1$ configuration window is saving 642.56 (Rupees/year).

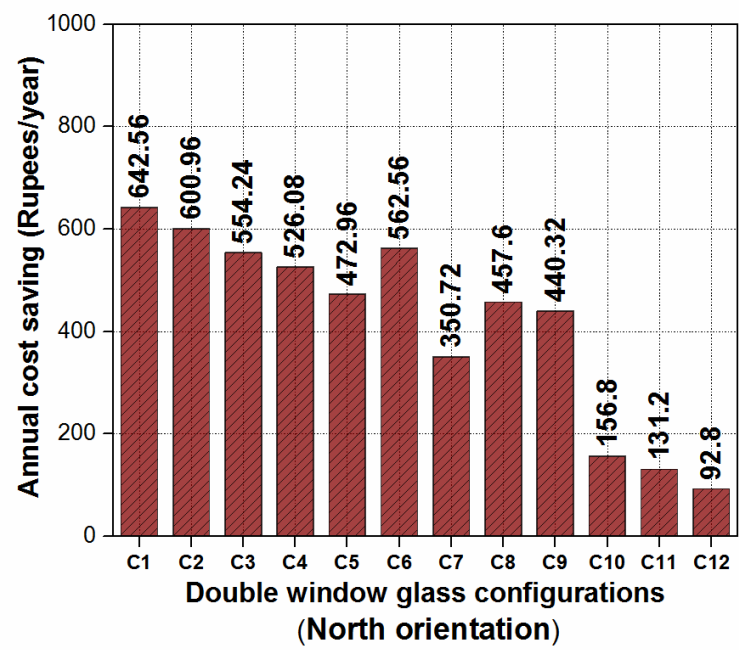

Figure 8. Annual cost savings per year of different double window glass configurations of Jodhpur climatic region in north orientation

In north east orientation from the graph of fig 9 it is clearly shown that $\mathrm{C} 1$ configuration window glass is more energy efficient and it is also saving more cost 744.32 (Rupees/year) when compared to all other double window glass configurations in Jodhpur climatic region.

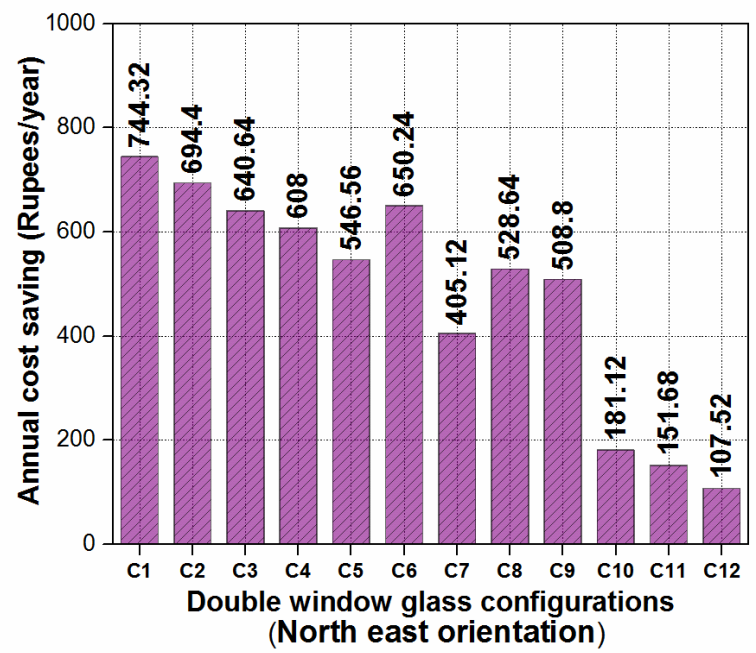

Figure 9. Annual cost savings per year of different double window glass configurations of Jodhpur climatic region in northeast orientation

In east orientation it is clearly shown that $\mathrm{C} 1$ configuration window glass is most energy efficient and it is also saving more cost 314.24 (Rupees/year) when compared to all other double window glass configurations in Jodhpur climatic region is shown in fig. 10 .

Fig. 11 clearly shows that in south east orientation C1 configuration window glass is more energy efficient and it is also saving more cost 3817.6 (Rupees/year) when compared to all other double window glass configurations in Jodhpur climatic region.

Fig 12 clearly shows that in south orientation C1 configuration window glass is more energy efficient and it is saving more cost 3667.2 (Rupees/year) when compared to all other double window glass configurations in Jodhpur climatic region.

From the graph in fig. 13 it is clearly seen that southwest orientation $\mathrm{C} 1$ configuration window glass is more energy efficient and it is also saving more cost 3719.04 (Rupees/year) when compared to all other double window glass configurations in Jodhpur climatic region.

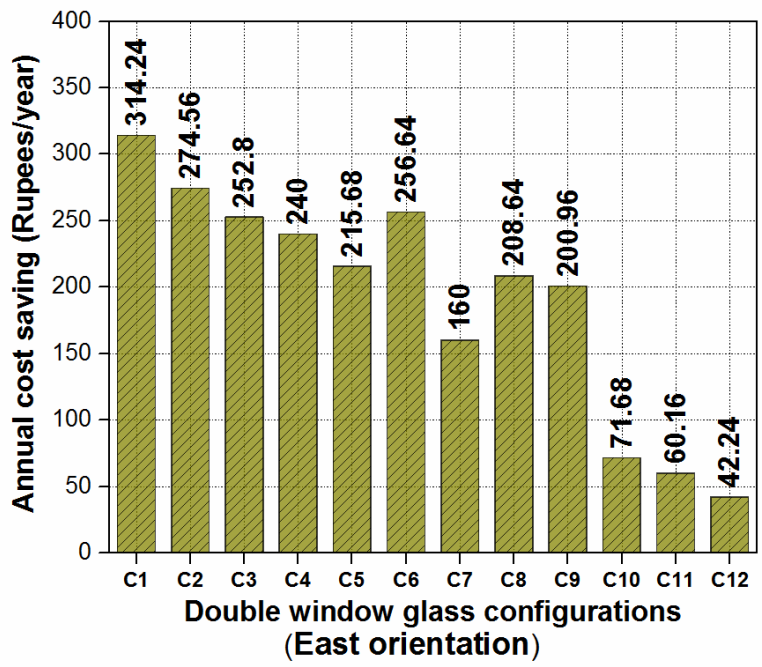

Figure 10. Annual cost savings per year of different double window glass configurations of Jodhpur climatic region in east orientation

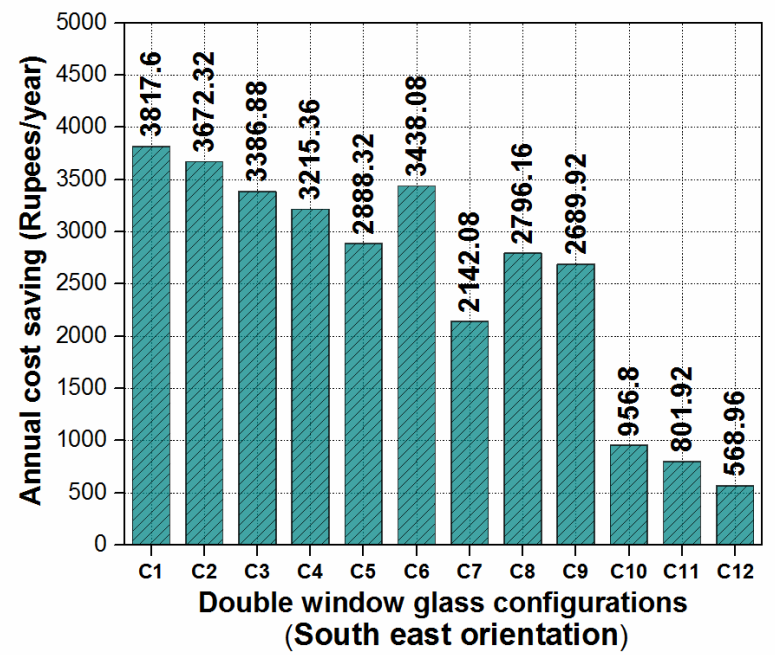

Figure 11. Annual cost savings per year of different double window glass configurations of Jodhpur climatic region in southeast orientation 


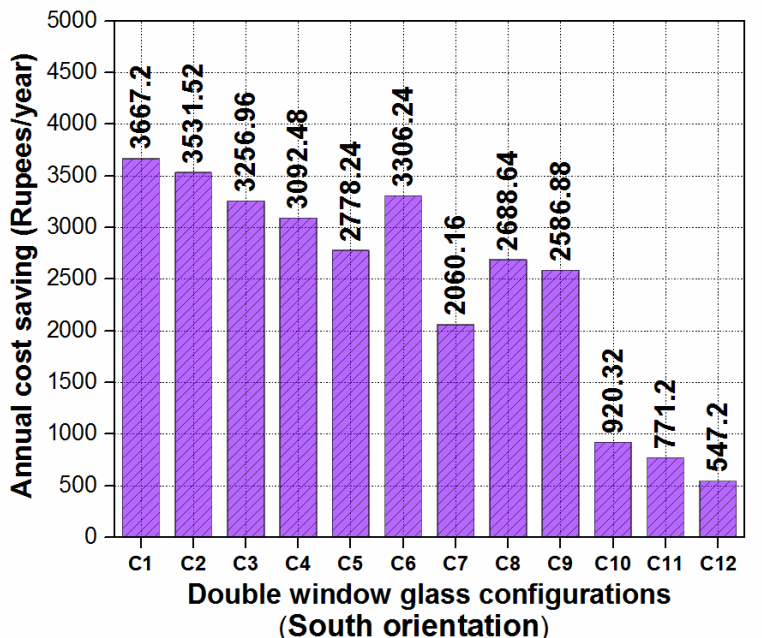

Figure 12. Annual cost savings per year of different double window glass configurations of Jodhpur climatic region in south orientation

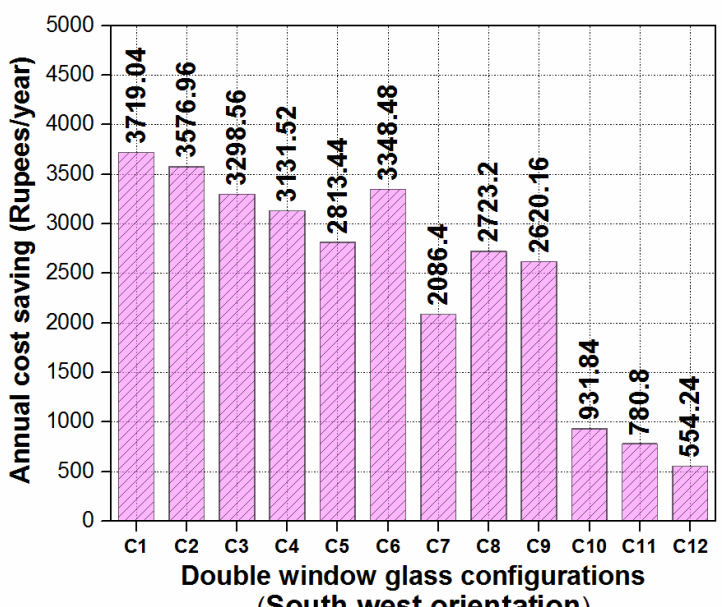

(South west orientation)

Figure 13. Annual cost savings per year of different double window glass configurations of Jodhpur climatic region in southwest orientation

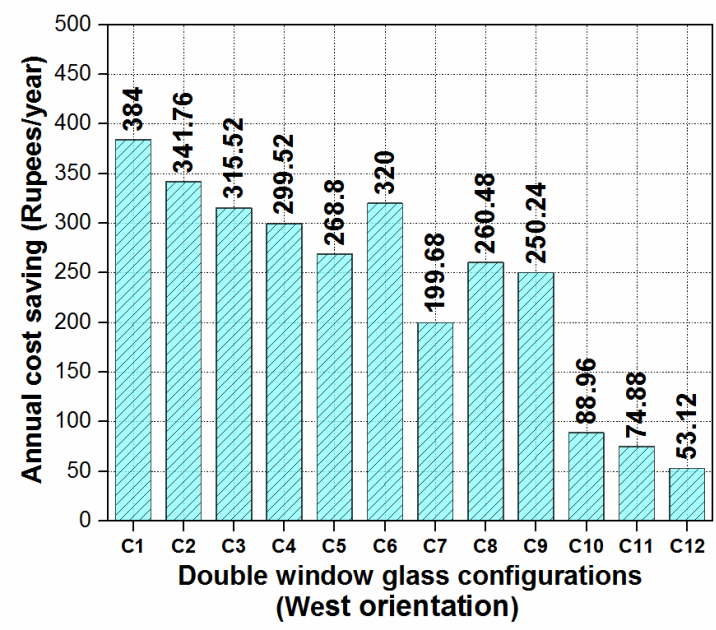

Figure 14. Annual cost savings per year of different double window glass configurations of Jodhpur climatic region in west orientation

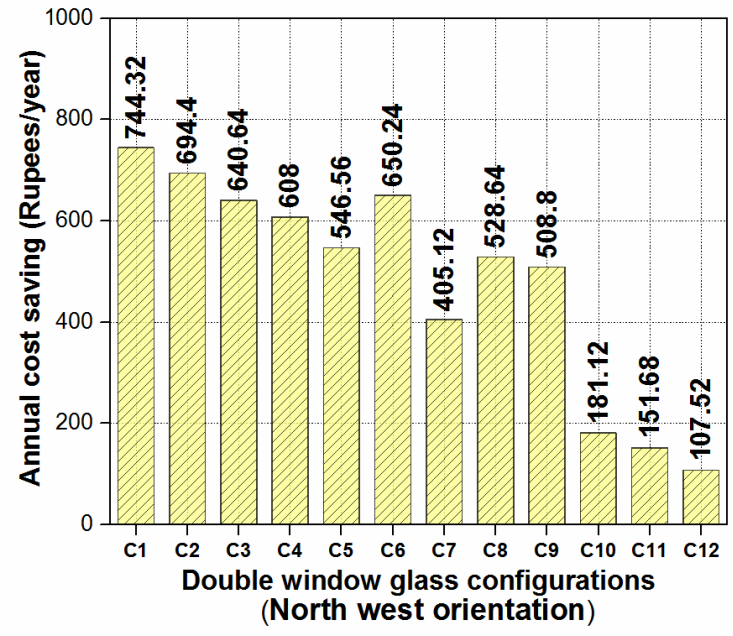

Figure 15. Annual cost savings per year of different double window glass configurations ofJodhpur climatic region in northwest orientation

Fig. 14 clearly shows that in west orientation C1 configuration window glass is more energy efficient and it is also saving more cost 384 (Rupees/year) when compared to all other double window glass configurations in Jodhpur climatic region.

Fig. 15 clearly shows that in northwest orientation $\mathrm{C} 1$ configuration window glass is more energy efficient and it is also saving more cost 744.32 (Rupees/year) when compared to all other double window glass configurations in Jodhpur climatic region.

\section{CONCLUSIONS}

The present work considers the annual cost savings of total solar radiation passing through different double glass window configurations in all orientations of hot \& dry (Jodhpur) climatic region.

- In south orientation C1 configuration window is more energy efficient to gain minimum heat in summer season, $\mathrm{C} 12$ configuration window is more energy efficient to gain maximum heat gain in winter season.

- In all orientations C1 configuration windows are more energy efficient in cost savings annually, in which southeast, southwest and south orientations $\mathrm{C} 1$ configuration windows are saving 3817.6(rupees/year), 3719.04(rupees/year) and 3667.2(rupees/year) respectively when compared to other configuration windows in all orientations.

\section{REFERENCES}

[1] Singh I, Bansal NK. (2011). Thermal and optical properties of different window systems in India. International journal of Ambient Energy 23(4): 201-211. https://doi.org/10.1080/01430750.2002.9674891

[2] Kirankumar G, Saboor S, Ashok Babu TP. (2016). Investigation of different window and wall materials for solar passive building design. Procedia Technology 692: 9-16. https://doi.org/10.4028/kem.2016.11.564

[3] Taleb AM, Al-Wattar AJH. (1988). Design of windows 
to reduce solar radiation transmittance into buildings. Solar \& Wind Technology 5: 503-515. https://doi.org/10.1016/0741-983X(88)90041-0

[4] Sujoy P, Biswanath R, Subhasis N. (2009). Heat transfer modeling on windows and glazing under the exposure of solar radiation. Energy \& Buildings 41: 654-661. https://doi.org/10.1016/j.enbuild.2009.01.003

[5] Jitka M, Hasim A. (2009). Evaluation of optical and thermal properties of window glazing. Wseas Transactions on Environment and Development 5: 86-93.

[6] Hee WJ, Alghoul MA, Bakhtyar B, OmKalthum E, Shameri MA, Alrubaih MS, Sopian K. (2015). The role of window glazing on day lighting and energy saving in buildings. Renewable Sustainable Energy Review 42: 323-343. https://doi.org/10.1016/j.rser.2014.09.020

[7] Wang TP, Wang LB. (2014). A steady heat transfer model of hollow double glazing under entire wave length heat radiation. Energy \& Buildings 81: 72-83. https://doi.org/10.1016/j.enbuild.2014.06.014

[8] Kirankumar G, Ashok Babu TP. (2015). Study of optimum inward glass tilt angle for window glass in different Indian latitudes to gain minimum heat into buildings. Energy Procedia 79: 1039-1045. https://doi.org/10.1016/j.egypro.2015.11.606

[9] Karmele Urbikain M, José MS. (2012). Heat transfer through a double-glazed unit with an internal louvered blind determination of the thermal transmittance using a biquadratic equation. International Journal of Heat and Mass Transfer 55: 1226-1235. https://doi.org/10.1016/j.ijheatmasstransfer.2011.09.032

[10] Kirankumar G, Saboor S, Ashok Babu, TP. (2017). Experimental and theoretical studies of window glazing materials of green energy building in Indian climatic zones. Energy Procedia 109: 306-313. https://doi.org/10.1016/j.egypro.2017.03.072

[11] Lai CM, Wang YH. (2011). Energy-saving potential of building envelope designs in residential houses in Taiwan. Energies 4: 2061-2076. https://doi.org/10.3390/en4112061

[12] Parishwad GV, Bhardwaj RK, Nema VK. (2011). Estimation of solar optical properties for windows. Architectural Science Review 42: 161-168. https://doi.org/10.1080/00038628.1999.9696873

[13] Anna M, Stefano L, Ludovica M, Giulia G. (2017). A procedure to evaluate the most suitable integrated solutions for increasing energy performance of the building's envelope, avoiding moisture problems. International Journal of Heat and Technology 35(4): 689 699. https://doi.org/10.18280/ijht.350401

[14] Furio C, Luka C, Alessandro DC, Sergio N. (2017). Comparison between different solar cooling thermally driven system solutions for an office building in Mediterranean Area. International Journal of Heat and Technology 35(1): 130-138. https://doi.org/10.1080/00038628.1999.9696873

[15] ASTM E424 (1971). Test for solar energy transmittance and reflectance (terrestrial) of sheet materials. Washington DC, USA, 1320-1326.

[16] ISO 9050:2003(E). Glass in building Determination of light transmittance, solar direct transmittance, total solar energy transmittance, ultraviolet transmittance and related glazing factors. 2003.

[17] BS EN 410 (1998). Glass in Building-Determination of luminous and solar characteristics of the glazing. British
Standards, 1-24.

[18] SP: 41 (S\&T) (1987). Handbook on functional Requirement of Buildings other than industrial buildings. Bureau of Indian Standards, India, 33-40.

[19] NBC (2005). National Building Code of India 2005, Section 1 Building and Services Lighting and Ventilation. Part 8, Bureau of Indian Standards, New Delhi, 2005, India.

[20] Mani A. (1982). Solar radiation over India. Allied publishers private limited. India.

[21] ECBC (2009). Energy Conservation Building Code. Bureau of Energy Efficiency, New Delhi, India.

[22] ASHRAE (2003). American society of heating and refrigerating and air conditioning engineers. Chapter 30, USA, 30.1-30.65.

[23] Parishwad GV, Bhardwaj RK, Nema VK. (2011). A theoretical procedure for estimation of solar heat gain factor for India. Architectural Science Review 41: 11-15. https://doi.org/10.1080/00038628.1998.9697402

[24] Parishwad GV, Bhardwaj RK, Nema VK. (1997). Estimation of hourly solar radiation for India. Renewable Energy 12(3): 300-313. https://doi.org/10.1016/S09601481(97)00039-6

[25] CIBSE. (2006). CIBSE Environmental Design Guide-A. 7thed. Chartered Institution of Building Services Engineers, London. U.K.

[26] Ishwar C, Shree K. (2011). Curtailment of intensity of solar radiation transmission through glazing in buildings at Delhi. Architectural Science Review 46: 167-174. https://doi.org/10.1080/00038628.2003.9696980

\section{NOMENCLATURE}

\begin{tabular}{|c|c|}
\hline $\mathrm{A}_{\mathrm{G}}$ & Area of the glass $\left(\mathrm{m}^{2}\right)$ \\
\hline A & $\begin{array}{l}\text { Solar radiation in absence of atmosphere } \\
\left(\mathrm{W} / \mathrm{m}^{2}\right)\end{array}$ \\
\hline $\mathrm{B}$ & Atmospheric extinction coefficient $\left(\mathrm{W} / \mathrm{m}^{2}\right)$ \\
\hline $\mathrm{C}$ & Dimensionless coefficient for sky radiation \\
\hline $\mathrm{C}_{\mathrm{o}}$ & Conductance of the air gap in (mm) \\
\hline $\mathrm{d}_{\mathrm{i}}$ & declination angle $\left({ }^{0} \mathrm{Deg}\right)$ \\
\hline $\mathrm{f}$ & Inward flowing fraction of energy \\
\hline $\mathrm{h}$ & hour angle $\left({ }^{0} \mathrm{Deg}\right)$ \\
\hline $\mathrm{k}$ & angle of window glass from vertical $\left({ }^{0} \mathrm{Deg}\right)$ \\
\hline 1 & latitude $\left({ }^{0} \mathrm{Deg}\right)$ \\
\hline $\mathrm{n}$ & number of days \\
\hline $\mathrm{I}_{\mathrm{DN}}$ & Solar radiation at normal incidence $\left(\mathrm{W} / \mathrm{m}^{2}\right)$ \\
\hline $\mathrm{I}_{\mathrm{DR}}$ & Direct solar radiation from the sun $\left(\mathrm{W} / \mathrm{m}^{2}\right)$ \\
\hline $\mathrm{I}_{\mathrm{dR}}$ & Diffuse radiation from the sky $\left(\mathrm{W} / \mathrm{m}^{2}\right)$ \\
\hline $\mathrm{I}_{\mathrm{GR}}$ & Ground reflected sun radiation $\left(\mathrm{W} / \mathrm{m}^{2}\right)$ \\
\hline $\mathrm{h}_{\mathrm{o}}$ & $\begin{array}{l}\text { Outside surface heat transfer coefficient } \\
\left(\mathrm{W} / \mathrm{m}^{2} \mathrm{~K}\right)\end{array}$ \\
\hline $\mathrm{h}_{\mathrm{i}}$ & $\begin{array}{l}\text { Inside surface heat transfer coefficient } \\
\left(\mathrm{W} / \mathrm{m}^{2} \mathrm{~K}\right)\end{array}$ \\
\hline ITSRGW & Total solar radiation through glass window $(\mathrm{kW})$ \\
\hline ITSRSGW & $\begin{array}{l}\text { Total solar radiation through single glass window } \\
(\mathrm{kW})\end{array}$ \\
\hline ITSRDGW & $\begin{array}{l}\text { Total solar radiation through double glass } \\
\text { window }(\mathrm{kW})\end{array}$ \\
\hline $\mathrm{q}_{\mathrm{ds}}$ & $\begin{array}{l}\text { Daily average solar radiation in summer } \\
\text { month }(\mathrm{kW})\end{array}$ \\
\hline $\mathrm{q}_{\mathrm{dw}}$ & $\begin{array}{l}\text { Daily average solar radiation in winter } \\
\text { month }(\mathrm{kW})\end{array}$ \\
\hline $\mathrm{T}_{\mathrm{SL}}$ & Solar transmittance $(\%)$ \\
\hline $\mathrm{R}_{\mathrm{SL}}$ & Solar reflectance $(\%)$ \\
\hline
\end{tabular}


Relative spectral distribution of the solar radiation $\left(\mathrm{W} / \mathrm{m}^{2}\right)$

C6

\section{Greek symbols}

$\lambda$
Wavelength (nm)

Wavelength interval (nm)

Solar absorptance of inside glass

Solar absorptance of outer glass

Solar altitude angle $\left({ }^{0} \mathrm{Deg}\right)$

Solar incidence angle ( $\left.{ }^{0} \mathrm{Deg}\right)$

Solar azimuth angle ( $\left.{ }^{0} \mathrm{Deg}\right)$

Surface solar azimuth angle $\left({ }^{0} \mathrm{Deg}\right)$

Ground reflectance factor

Spectral transmission (\%)

Spectral reflection (\%)

Spectral absorption (\%)

Grey glass window-Air gap $10 \mathrm{~mm}-$ Green glass window

Grey glass window- Air gap 10mm-Bronze glass window

Grey glass window- Air gap 10mm -Clear glass window

Green glass window- Air gap 10mm -Bronze glass window

Green glass window- Air gap 10mm -Clear glass window

\section{Subscripts}

$\begin{array}{ll}\text { ds } & \text { Daily solarr adiation in summer months } \\ \text { dw } & \text { Daily solarr adiation in winter months } \\ \text { DR } & \text { Direct solar radiation } \\ \text { dR } & \text { Diffuse solar radiation } \\ \text { GR } & \text { Ground reflected solar radiation } \\ \text { SHGC } & \text { Solar heat gain coefficinet of single glass } \\ \text { SHGC } & \text { Solar heat gain coefficinet of double glass } \\ \text { TSR } & \text { Total solar radiation } \\ \text { TSRSGW } & \text { total solar radiation through single glass } \\ & \text { window } \\ \text { TSRDGW } & \text { total solar radiation through double glass } \\ & \text { window }\end{array}$

Green glass window- Air gap 10mm -Grey glass window

Bronze glass window- Air gap 10mm -Clear glass window

Bronze glass window- Air gap 10mm -Grey glass window

Bronze glass window- Air gap 10mm -Green glass window

Clear glass window- Air gap 10mm -Grey glass window

Clear glass window- Air gap 10mm -Green glass window

Clear glass window- Air gap 10mm -Bronze glass window 